\title{
A beginner's guide to sex
}

\section{John Launer}

Most doctors know remarkably little about sex. They may have learned the facts of life at school, studied family planning and sexually transmitted diseases as medical students, and had some personal experience of sexual relationships. Yet they are unlikely to have had any serious teaching about evolution, and hence to understand very much about the biological role of sex. This is a pity. Sex is a fascinating subject, not just in the most obvious sense, but because discoveries in biology in recent decades have given us a far greater understanding of males and females, and the interactions between them. In this article, I want to offer a brief review of what we now know about the evolutionary biology of sex, and the consensus that is emerging around sexual psychology.

Sexual reproduction began around a billion years ago. For around two and a half billion years before then, it was unknown: every organism reproduced by dividing rather than by coupling with another. So why didn't every species carry on splitting rather than splicing? Darwin thought he knew the answer. He considered it the best way of producing variation in a species and therefore the widest range of different types that might survive in a changing environment. But in this case Darwin was wrong.

Since Darwin's time it has become clear that you do not actually need sexes for this purpose: variation happens anyway, mainly through errors of DNA transcription. More important, selfish gene theory makes it clear that no individual can possibly be interested in doing something only to the advantage of the whole species. ${ }^{1}$ As the evolutionary biologist Maynard Smith argued, it is very hard to understand why any female should want to give up half her DNA, especially as the males of many species do little of any use except wait around for sex, and fight with rivals. To clinch the argument, the fossil evidence shows that survival in the long run happens more or less at random: whole species in their thousands get

Correspondence to: Dr John Launer, London Department of Postgraduate Medical Education, Stewart House, 32 Russell Square, London WC1B 5DN, UK; jlauner@londondeanery.ac.uk washed away periodically by catastrophes like giant meteorites, and it is pretty immaterial whether they were able to reproduce sexually or not.

\section{MALES AND FEMALES}

What we do know for certain is that there is only one consistent difference between males and females across all the species. Females produce small numbers of relatively large immobile sex cells-eggsthat carry a significant supply of their own nutrition around them. Males, by contrast, produce prodigious amounts of lean, mobile sex cells-sperm-that lack any of their own nutritional stores. Before sexual reproduction evolved, it is therefore very likely that one or more asexual organisms diverged into separate tendencies: fat and immobile on the one hand, and lean and mobile on the other. Each of these then became imperilled in their own right in terms of survival, but they compensated for this by learning to pair up. They became dependent on splicing together the genes of a large immobile cell with that of a small mobile one, hence making sexual reproduction a necessity.

There are a number of competing theories about why this happened. Currently the most credible theory is that it helped species keep ahead of lethal pathogens, especially parasites. ${ }^{2}$ If true, this means that each sex was prepared to give up a very great deal in order to protect itself against alien threats. Whatever the reason for the emergence of sexual reproduction, it presents an inescapable challenge: how do you attract a mate of the opposite sex, while also doing your best to promote the replication and survival of your own specific genes as an individual rather than those of your mate?

The ways in which different species have evolved answers to this question are innumerable and sometimes staggering. Each answer is different and unique. But they all share one thing in common. In the language of evolutionary biology, they are "selfish". As is the case with selfish genes, this is not a moral judgement or a way of suggesting that the males and females of each species get together and consciously decide on a way of outwitting the opposite sex. It simply means that males and females are under constant pressure to find ways of gaining advantage over each other.

\section{BEHAVIOUR STRATAGEMS}

The study of behaviour stratagems practised by the two sexes in the struggle to replicate their own genes has now claimed a central place in the field of biology and the life sciences. We know an enormous amount about the way that male and female ants, jellyfish, dolphins, giraffe and thousands of other species relate in the pursuit of reproduction. Indeed, it has become a topic of fascination not just to biologists but in modern culture generally. These days, the average intelligent 12 year-old is likely to know that the female mantis bites off the male's head during sex, and that female angler fish carry their males as specks on their backs.

Human sexual behaviour is inherently rivalrous between the sexes as it is with any other species. This rivalry exactly reflects the interests of egg carriers and sperm carriers. One episode of sexual intercourse requires little investment by a man, but will potentially lead to a 9 month pregnancy followed by up to two decades of childrearing by a woman. It is not surprising that-across all cultures-men largely desire youth, beauty and variety, while women largely desire strength, economic and social status, and a capacity for commitment. Conflicts between the sexes are the social rule, not the exception. They include arguments over the initiation of sex during courtship, bickering over money and commitment in marriages, separation and divorce, sexual harassment in private or public, and serious sexual assault. In every culture, exaggeration and deception are practised in order to achieve extramarital couplings.

\section{INDIVIDUAL CHOICE}

What men and women desire is not the same, and the strategies of one sex do not meet the needs of the other. Much that men and women do in their mating behaviour is oriented towards maximising replication within the constraints of competition between members of the same sex and-more relevantly-between the man and woman in each pairing. As the evolutionary psychologist David Buss points out, lifelong sexual fidelity brings its own rewards, but it comes at a price for both sexes in relinquished opportunities. ${ }^{3}$

"Wishes and denials," Buss writes, "will not make psychological differences 
disappear, any more than they will make beard growth or breast development disappear. Harmony between men and women will be approached only when these denials are swept away and we squarely confront the differing desires of each sex." It is an audacious claim. Yet the facts, like the biology, are indisputable. As Buss argues, we can deny them, use them as a justification for ruthlessness, or apply them as insights into our own desires, fantasies and behaviour. Ultimately, what we do with them remains a matter of individual choice.

Competing interests: None declared.

Provenance and peer review: Commissioned; not externally peer reviewed.
Postgrad Med J 2009;85:631-632.

doi:10.1136/pgmj.2009.090639

\section{REFERENCES}

1. Dawkins R. The selfish gene. Oxford: Oxford University Press, 1989.

2. Ridley M. The Red Queen: sex and the evolution of human nature. London: Viking, 1993.

3. Buss D. The evolution of desire: strategies of human mating. New York: Basic Books, revised ed, 2003.

\section{Access a vast information database with Toll-Free linking}

"Toll-free" linking gives you immediate access to the full text of many of the cited articles in a paper's reference list-FOR FREE. With the support of HighWire's vast journal catalogue, a huge reference library is now open to you. If HighWire hosts the journal, you can view the full text of the referenced article, completely free of charge by following the Free Full Text links in the references. 